\title{
Field Mapping, Geochemistry and Petrology of Basement Complex Rocks around Akungba-Akoko, Southwestern Nigeria
}

Ehinola, Q. I. ${ }^{1}$ Oluwajana, O. A. ${ }^{1}$ and Ogunleye C. A. ${ }^{1}$ ${ }^{1}$ Department of Earth Sciences, Adekunle Ajasin University, P.M.B. 001, AkungbaAkoko, Nigeria ${ }^{1}$

Field mapping, geochemical and petrographic studies of the Basement Complex rocks around Akungba-Akoko were carried out with the aim of determining the various rock types, their chemical constituents and mode of origin.

The field studies revealed that migmatite, granite gneiss and biotite gneiss intruded by biotite granite, charnockite and minor felsic and basic rocks were the main rock types. Seven rock samples comprising of granite gneiss (2), biotite gneiss (2), biotite granite (2) and charnockite (1) were collected for Scan Electron Microscopy (SEM), X-Ray Flourescence (XRF) and petrographic analyses.

Most of the rocks show an enrichment in $\mathrm{SiO}_{2}, \mathrm{Al}_{2} \mathrm{O}_{3}$ and $\mathrm{Fe}_{2} \mathrm{O}_{3}$ compared to $\mathrm{CaO}, \mathrm{Na}_{2} \mathrm{O}, \mathrm{K}_{2} \mathrm{O}$ and $\mathrm{MgO}$. The gneisses and granitoids of the area are enriched in quartz, feldspars and mica and are of granitic origin. Using variation diagrams, it was revealed that the granite gneiss and biotite gneiss are orthogneisses which are derived from metamorphism of granitic composition. The biotite granite and charnockite are of igneous/magmatic origin. The igneous protolith(s) of the granite gneiss and biotite gneiss are S-type granitoids probably derived from shallow crustal or metasedimentary rocks; the biotite granite is I-type granitoid derived from crustal igneous rocks and the charnockite is Mtype granitoid derived from mantle or deeper crustal source.

The mode of origin of rocks around Akungba-Akoko are igneous, metamorphic and sedimentary in nature. 